\title{
DIETARY TREATMENT OF A CHILD WITH MAPLE SYRUP URINE DISEASE (BRANCHED-CHAIN KETOACIDURIA)
}

\author{
BY \\ R. G. WESTALL \\ From The Medical Unit, University College Hospital Medical School, London
}

(RECEIVED FOR PUBLICATION MARCH 18, 1963)

\begin{abstract}
Maple syrup urine disease is one of a number of cerebro-degenerative conditions, which is caused, directly or indirectly, by a congenital defect in amino acid metabolism. However, in contrast to other diseases of a similar type, notably phenylketonuria, the affected children frequently die within the first month and the survivors rarely live for longer than two years (Menkes, Hurst and Craig, 1954). In 1957, Westall, Dancis and Miller reported that in this disease the blood and urine contained excessive amounts of leucine, isoleucine, valine and methionine. This has since been confirmed in other cases, and it was further reported that the keto and hydroxy acid analogues of these amino acids were also present in the urine (Menkes, 1959; Dancis, Levitz, Miller and Westall, 1959; Mackenzie and Woolf, 1959). Recently Norton, Roitman, Snyderman and
\end{abstract} Holt (1962) have shown that methionine was implicated incorrectly through an analytical error. It so happened that the methionine peak on the flow sheet obtained by the Moore and Stein (1954) ion-exchange column method for amino acid analysis was exactly superimposed on a peak due to an unidentified substance. Norton et al. (1962) using a modification of the above method (Piez and Morris, 1960) have separated the two substances and tentatively identified the unknown as alloisoleucine, a substance which hitherto had not been found in body fluids. This simplifies our biochemical concepts of the disease, as alloisoleucine is clearly more closely related to the other three branched-chain amino acids than is methionine.

Dent and Westall (1961) studied a further case of maple syrup urine disease who had survived till 9 months of age. They were able to show that the high plasma content of leucine, isoleucine and valine (and of the alloisoleucine, still then thought to be methionine) could be reduced to normal levels by suitably restricting the content of these three amino acids in the diet. Unfortunately no clinica improvement was obtained, probably because the cerebral damage which had already taken place by that time was irreversible. We did suspect that the rate of deterioration might have been slowed or even arrested. However, we were hopeful that a restricted diet of this nature would be useful provided that it was given much earlier. Meanwhile, Holt, Snyderman, Dancis and Norton (1960) had reported feeding a diet with a carefully controlled content of leucine, isoleucine and valine and methionine to a 14-day-old infant with the disease. At 7 months of age they believed that the child was neurologically and mentally normal but now, at 3 years of age, Dr. L. E. Holt, Jr. (private communication) considers that their earlier assessment of the patient's mental condition was overoptimistic. This paper relates the experience of applying a similar type of diet to an infant with this disease.

\section{Case History}

L.O'C. was born in the Obstetric Department of University College Hospital, London, following a normal pregnancy. She was the third sibling of healthy parents with no history of consanguinity. The father was a manual worker of Irish extraction; the mother was English. The first sibling, C.O'C., kindly referred to us for study by Professor A. Moncrieff, had maple syrup urine disease and died at 15 months. She was the subject of a previous dietary trial (Dent and Westall, 1961). The second child, now 2 years old, has been watched from birth and is clinically and biochemically normal. L.O'C. was an apparently normal baby; weight $6 \mathrm{lb} .4 \mathrm{oz}$. $(2,834 \mathrm{~g}$.$) , length 19 \frac{1}{2} \mathrm{in} .(49 \cdot 5 \mathrm{~cm}$.$) , and with a head$ circumference of $13 \frac{1}{2}$ in. $(34 \cdot 3 \mathrm{~cm}$.). Moro and grasp reflexes were normal. On the evening of the fifth day she showed a reluctance to feed and a sample of urine collected during the following day had the characteristic smell of maple syrup. Examination at this time revealed no definite abnormality in the central nervous system, 


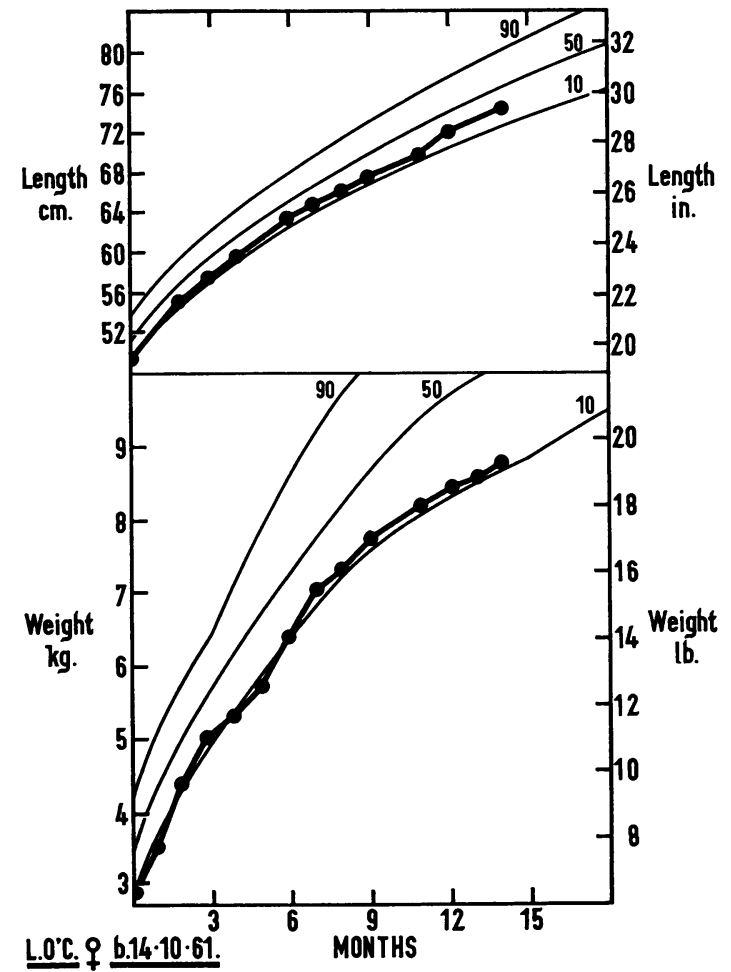

Fig. 1.-Growth data of the patient, L.O'C. The normal percentiles are copied from the charts prepared by Dr. H. C. Stuart (Children's Medical Center, Boston, Mass., U.S.A.).

except that the Moro reflex was sluggish. During the evening of the sixth day the artificial diet, to be described later, was introduced. On the next day the patient fed badly, going limp during the feed, some of which was given by tube. On the eighth day she took her feed voluntarily and was more lively. Progress was maintained and the odour of maple syrup had disappeared from the urine by the tenth day. Unfortunately we did not obtain an electroencephalogram during this early period.

From then on progress was satisfactory. Regular examination of the central nervous system showed no abnormality. Her weight was just below the 10 th percentile and her length, at first on the 10th, reached the 25th percentile by the fifth month (Fig. 1). The head circumference was on the 25 th percentile throughout. She first smiled at $3 \frac{1}{2}$ weeks and her other milestones were reached in normal times. The only cause for concern was an unexplained anaemia when she was between 1 and 3 months old. Her haemoglobin was rather low at birth $(14.7 \mathrm{~g} . / 100 \mathrm{ml}$.) and this fell to $8.5 \mathrm{~g} . / 100 \mathrm{ml}$. during the following five weeks. This was associated with a reticulocyte count of $5 \cdot 8 \%$. Further investigations showed total serum bilirubin $0.6 \%$; prothrombin concentration $100 \%$; a negative

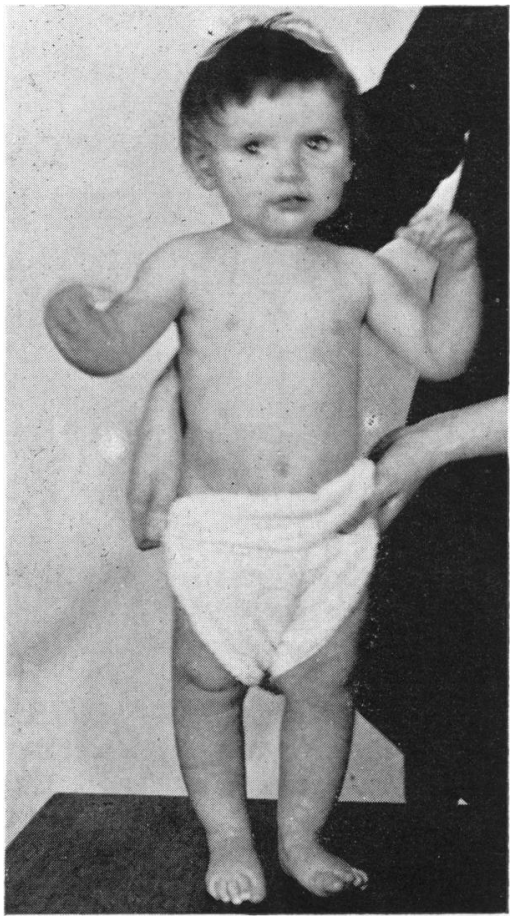

FIG. 2.-The patient, L.O'C., at 1 year of age.

direct Coombs' test; Group A, rhesus positive; and no excess urobilinogen in the urine. However, three estimations of occult blood in the stools were strongly positive and in view of this she was given a barium meal and examined radiologically. There was no abnormality in the oesophagus, stomach or duodenum. Trace metals in the mineral mixture used in the diet came under suspicion, but temporary elimination of these had no beneficial effect. However, spontaneous improvement slowly occurred, and at 3 months the haemoglobin had risen to $10.2 \mathrm{~g} . / 100 \mathrm{ml}$. with a reticulocyte count of $1.9 \%$.

At 3 months she was vaccinated. A typical primary reaction with pustule formation was obtained and a faint smell of maple syrup was noticed in the urine. Two weeks later she developed a cough with a few râles over the lingula and right middle lobe. Treatment with streptomycin and penicillin was successful, but several times during this episode, which lasted for 10 days, the smell of maple syrup returned to the urine. She was sent home when 5 months old and she attended periodically as an out-patient.

When 8 months old L.O'C. was readmitted to U.C.H. with bilateral otitis media. She was treated with penicillin i.m. for seven days and then orally for two days. 
TABLE 1

PLASMA AMINO ACIDS (mg./100 ml.)

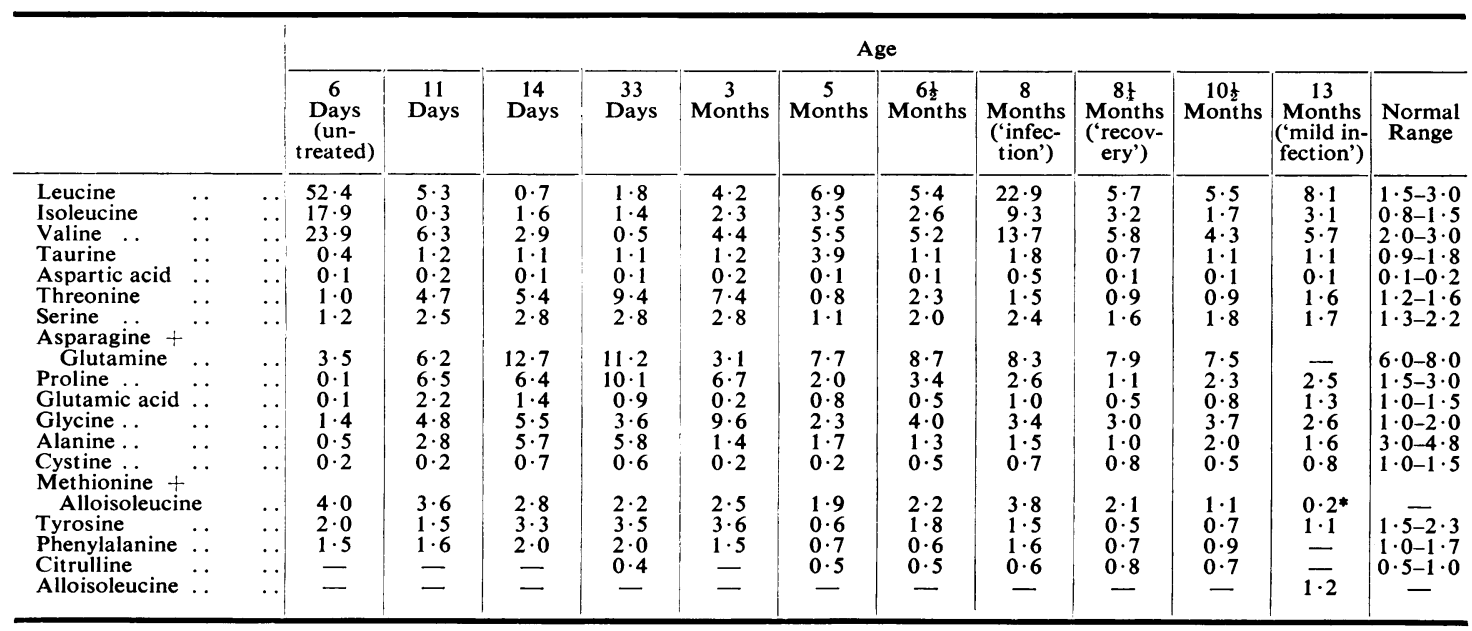

* Methionine.

Dashes indicate that no analysis was obtained for technical reasons.

Her temperature returned to normal after three days and by the sixth day she was taking the full amount of her feeds. Once again, at the height of her fever, there was a strong smell of maple syrup in the urine. In three weeks she was quite well again and she returned home. At the time of writing (November 1962) L.O'C. is 13 months old (Fig. 2). Two further admissions for minor ailments, which proved to be of short duration, were made.

Intelligence. The patient has been seen on several occasions by Miss G. Rawlings of the Department of Psychological Medicine, University College Hospital, who has reported as follows:

At 3 weeks of age. 'Already her movements show a good range; her regard is more than a fleeting glance, she is able to follow a moving light with her eyes and her finger grasp is normal.'

At 35 weeks of age. 'On the Griffiths Development Scale she has a mental age of 32 weeks which gives her a developed mental quotient of 90 . This may be a slight under-estimate since it was difficult to elicit some of the responses that I needed to observe.'

At 55 weeks of age. 'On this occasion her Developmental Quotient was 97. There is every reason to be confident that this child's development is normal.'

Biochemical Investigations. The analytical methods used have been described fully elsewhere (Dent and Westall, 1961).

Examination of the cord blood plasma for amino acids by paper chromatography showed a normal pattern and likewise the amino acids and keto acids excreted by the infant during the first three days were normal. However, on the fourth to sixth days the urinary excretion of keto acids rose dramatically and these keto acids were identified as $\alpha$-oxoisocaproic, $\alpha$-oxo $\beta$ methylvaleric and $\alpha$-oxoisovaleric acids. A paper chromatogram of the blood plasma amino acids present on the fourth day showed an abnormally high level of leucine, isoleucine and valine. This was confirmed by a quantitative determination of the plasma amino acids present in the blood on the sixth day (using the Spackman, Stein and Moore (1958) automatic amino acid analyser). At this time the levels were leucine $52 \mathrm{mg}$, isoleucine $18 \mathrm{mg}$. and valine $24 \mathrm{mg}$. per $100 \mathrm{ml}$. of blood plasma. These figures (see Table 1) were 10-20 times higher than normal and, taken in conjunction with the high keto acid excretion and the maple syrup smell in the urine, confirmed the diagnosis of maple syrup urine disease.

On transfer to the new dietary régime the patient's urine continued to be examined for keto acids each day. The fall in keto acid excretion was gradual, but by the thirteenth day the level was reduced to near normal limits. On the eleventh day, the blood plasma levels of leucine, isoleucine and valine were $5 \cdot 3,0.23$ and $6.26 \mathrm{mg}$. per $100 \mathrm{ml}$. A small dietary supplement of isoleucine was given and by the fourteenth day the values were 0.72 , 1.76 and $2.88 \mathrm{mg} . / 100 \mathrm{ml}$. respectively. Further analyses are shown in Table 1 . While the child was clinically well and growth was adequate, only weekly checks on the keto acid excretion and occasional determinations of the blood plasma amino acids were performed.

On readmission to U.C.H. with otitis media, when 8 months old, her blood plasma levels of leucine, isoleucine and valine were $22.9,9.3$ and $13.7 \mathrm{mg}$. per $100 \mathrm{ml}$. respectively. However, with remission of the fever and a temporary lowering of the intake of the branched-chain amino acids, the plasma levels fell to more normal limits within a few days. 
TABLE 2

DIET (g./day unless stated otherwise)

\begin{tabular}{|c|c|c|c|c|c|c|c|c|c|c|}
\hline & & & $\begin{array}{c}\text { First 28-day } \\
\text { Period }\end{array}$ & $\begin{array}{l}\text { Second } \\
\text { Month }\end{array}$ & $\begin{array}{l}\text { Third } \\
\text { Month }\end{array}$ & $\begin{array}{l}\text { Fourth } \\
\text { Month }\end{array}$ & $\underset{\text { Month }}{\text { Fifth }}$ & $\begin{array}{l}\text { Sixth } \\
\text { Month }\end{array}$ & $\begin{array}{l}\text { Seventh } \\
\text { Month }\end{array}$ & $\begin{array}{l}\text { Eighth } \\
\text { Month }\end{array}$ \\
\hline $\begin{array}{l}\text { Amino acid mixture } \\
\text { 1-alanine .. } \\
\text { 1-aspartic acid } \\
\text { 1-glutamic acid } \\
\text { 1-cystine .. } \\
\text { 1-histidine } \\
\text { 1-proline . . } \\
\text { 1-phenylalanine } \\
\text { 1-tyrosine } \\
\text { 1-serine ... } \\
\text { 1-threonine } \\
\text { 1-arginine } \\
\text { 1-lysine HCl } \\
\text { 1-tryptophan } \\
\text { 1-methionine } \\
\text { Glycine .. }\end{array}$ & $\begin{array}{l}e \\
\ldots \\
\cdots \\
\cdots \\
\ldots \\
\cdots \\
\ldots \\
\cdots \\
\cdots \\
\cdots \\
\cdots \\
\cdots \\
\ldots\end{array}$ & $\begin{array}{l}\cdots \\
\cdots \\
\cdots \\
\cdots \\
\cdots \\
\cdots \\
\cdots \\
\cdots \\
\cdots \\
\cdots \\
\cdots \\
\cdots\end{array}$ & $\begin{array}{l}0.72 \\
1.60 \\
3.92 \\
0.72 \\
0.48 \\
1.40 \\
0.96 \\
0.88 \\
0.92 \\
0.92 \\
0.80 \\
1 \cdot 12 \\
0.36 \\
0.40 \\
0.48\end{array}$ & $\begin{array}{l}0.84 \\
1 \cdot 87 \\
4 \cdot 55 \\
0.84 \\
0.56 \\
1.63 \\
1 \cdot 12 \\
1 \cdot 03 \\
1 \cdot 07 \\
1 \cdot 07 \\
0.93 \\
1 \cdot 30 \\
0.42 \\
0.46 \\
0.56\end{array}$ & $\begin{array}{l}0.40 \\
1.00 \\
2.00 \\
0.90 \\
0.56 \\
0.70 \\
0.43 \\
1.05 \\
0.96 \\
0.23 \\
0.66 \\
0.45 \\
0.10 \\
0.10 \\
1.00\end{array}$ & $\begin{array}{l}0 \cdot 46 \\
1 \cdot 16 \\
2 \cdot 32 \\
1 \cdot 04 \\
0 \cdot 65 \\
0 \cdot 81 \\
0 \cdot 50 \\
1 \cdot 21 \\
1 \cdot 11 \\
0 \cdot 27 \\
0 \cdot 76 \\
0 \cdot 52 \\
0 \cdot 12 \\
0 \cdot 12 \\
1 \cdot 16\end{array}$ & $\begin{array}{l}0 \cdot 46 \\
1 \cdot 16 \\
2 \cdot 32 \\
1 \cdot 04 \\
0 \cdot 65 \\
0 \cdot 81 \\
0 \cdot 50 \\
1 \cdot 21 \\
1 \cdot 11 \\
0 \cdot 27 \\
0 \cdot 76 \\
0 \cdot 52 \\
0 \cdot 12 \\
0 \cdot 12 \\
1 \cdot 16\end{array}$ & $\begin{array}{l}0 \cdot 46 \\
1 \cdot 16 \\
2 \cdot 32 \\
1 \cdot 25 \\
0 \cdot 65 \\
0 \cdot 81 \\
0 \cdot 89 \\
1 \cdot 23 \\
1 \cdot 11 \\
0 \cdot 54 \\
0 \cdot 77 \\
0 \cdot 53 \\
0 \cdot 23 \\
0 \cdot 24 \\
1 \cdot 16\end{array}$ & $\begin{array}{l}0 \cdot 46 \\
1 \cdot 16 \\
2 \cdot 32 \\
1 \cdot 25 \\
0 \cdot 65 \\
0 \cdot 81 \\
0 \cdot 89 \\
1 \cdot 23 \\
1 \cdot 11 \\
0 \cdot 54 \\
0 \cdot 77 \\
0 \cdot 53 \\
0 \cdot 23 \\
0 \cdot 24 \\
1 \cdot 16\end{array}$ & $\begin{array}{l}0 \cdot 46 \\
1 \cdot 16 \\
2 \cdot 32 \\
1 \cdot 25 \\
0 \cdot 65 \\
0 \cdot 81 \\
0 \cdot 89 \\
1 \cdot 23 \\
1 \cdot 11 \\
0 \cdot 54 \\
0 \cdot 77 \\
0 \cdot 53 \\
0 \cdot 23 \\
0 \cdot 24 \\
1 \cdot 16\end{array}$ \\
\hline Total & $\ldots$ & $\ldots$ & $15 \cdot 68$ & $18 \cdot 23$ & $10 \cdot 54$ & $12 \cdot 21$ & $12 \cdot 21$ & $13 \cdot 35$ & $13 \cdot 35$ & $13 \cdot 35$ \\
\hline $\begin{array}{l}\text { Gelatin } \\
\text { Liquid milk (ml.) } \\
\text { Skimmed milk (dry } \\
\text { Arachis oil (ml.) } \\
\text { Sucrose .. } \\
\text { Baker's yeast } \\
\text { Mashed carrot } \\
\text { Apple purée (tsp.) } \\
\text { Mineral mixture } \\
\text { Vitamin mixture }\end{array}$ & $\begin{array}{l}\ldots \\
\cdots \\
\cdots \\
\cdots \\
\cdots \\
\cdots\end{array}$ & $\begin{array}{l}\cdots \\
\cdots \\
\cdots \\
\cdots \\
\cdots \\
i \\
\xi\end{array}$ & $\begin{array}{c}75-100 \\
20 \\
40\end{array}$ & $\begin{array}{c}110-130 \\
23 \\
46\end{array}$ & $\begin{array}{r}5 \cdot 0 \\
120 \\
30 \\
60\end{array}$ & $\begin{array}{r}5 \cdot 8 \\
130 \\
\\
36 \\
72 \\
2 \\
2\end{array}$ & $\begin{array}{r}5 \cdot 8 \\
135 \\
\\
36 \\
72 \\
5 \\
2 \\
2\end{array}$ & $\begin{array}{c}5 \cdot 8 \\
13 \cdot 4 \\
40 \\
75 \\
5 \\
3 \\
3\end{array}$ & $\begin{array}{c}5 \cdot 8 \\
13 \cdot 4 \\
40 \\
75 \\
10 \\
3 \\
3\end{array}$ & $\begin{array}{c}7 \cdot 0 \\
15 \cdot 0 \\
45 \\
75 \\
10 \\
4 \\
4\end{array}$ \\
\hline
\end{tabular}

Mineral mixture $(A)$ : Calcium lactate $4.5 \mathrm{~g}$., calcium chloride $\left(\mathrm{CaCl}_{2}, 2 \mathrm{H}_{2} \mathrm{O}\right) \mathbf{0} \cdot 3 \mathrm{~g}$. , dipotassium hydrogen phosphate $1 \cdot 5 \mathrm{~g}$. disodium hydrogen phosphate $1.0 \mathrm{~g}$, magnesium sulphate $0.8 \mathrm{~g}$., ferrous sulphate $20 \mathrm{mg}$., copper sulphate 2 mg., zinc chloride 2 mg., manganese sulphate $2 \mathrm{mg}$., potassium iodide $80 \mu \mathrm{g}$., potash alum $30 \mu \mathrm{g}$., cobalt sulphate $30 \mu \mathrm{g}$., sodium molybdate $30 \mu \mathrm{g}$.

Mineral mixture $(B)$ : Anhydrous sodium carbonate $0.17 \mathrm{~g}$. , potassium carbonate $0.22 \mathrm{~g}$. , and calcium carbonate $0.31 \mathrm{~g}$.

Vitamin mixture $(A)$ : Vitamin A 5,000 i.u., vitamin D 1,000 i.u., aneurine $1.0 \mathrm{mg}$., riboflavine $0.4 \mathrm{mg}$. , pyridoxine $0.5 \mathrm{mg}$., nicotinamide

$5.0 \mathrm{mg}$., and ascorbic acid $25 \mathrm{mg}$.

Vitamin mixture $(B)$ : Folic acid $0.5 \mathrm{mg}$., choline chloride $75 \mathrm{mg}$., p-aminobenzoic acid $1.0 \mathrm{mg}$. , inositol $1.0 \mathrm{mg}$., biotin $50 \mu \mathrm{g} .$, vitamin $\mathrm{B}_{12} 10 \mu \mathrm{g}$.

Calcium pantothenate $5.0 \mathrm{mg}$. was incorporated with the amino acid mixture as it caused precipitation if added to the vitamin mixture.

On two occasions (at the age of 7 months and 1 year) on obtaining a positive keto acid reaction in the urine, investigation of the nature of the keto acid showed that it was not, as expected, one or more of the branchedchain keto acids but was p-hydroxyphenylpyruvic acid. This keto acid is derived from tyrosine and might be excreted if there was an appreciable amount of d-tyrosine in the sample of 1-tyrosine used in the diet. On the other hand p-hydroxyphenylpyruvic acid is frequently excreted by premature babies (Levine, Gordon and Marples, 1941), and even by some full-term infants (Bloxam, Day, Gibbs and Woolf, 1960), and the conditions that lead to this excretion are alleviated by the addition of extra ascorbic acid to the diet. On the latter assumption L.O'C. was given an additional supplement of $100 \mathrm{mg}$. of ascorbic acid per day. The second occasion when the presence of p-hydroxyphenylpyruvic acid in the urine was confirmed followed a period when the additional ascorbic acid was accidentally omitted. It was then restored to the diet.

The Dietary Régime. Dietary trials with the elder sibling in the family (Dent and Westall, 1961) led us to conclude that, in this disease, the high blood plasma levels of leucine, isoleucine and valine could be reduced to normal levels by providing a diet in which these essential branched-chain amino acids were limited to the minimum amounts required to maintain normal growth. As we pointed out, there is no easy way of devising such a diet from natural foods without reducing the total protein content to an unrealistic level (about 3-4 g. of protein per day). In the diet for L.O'C. it was decided to use fresh skimmed cows' milk as a source of the required amounts of leucine, isoleucine and valine. Fortunately the relative proportions of these amino acids in the milk protein are about right for human growth requirements L.O'C. did, however, require a small valine supplement. To compensate for the low protein the remaining 1 -amino acids were given in proportions and in amounts similar to those given by a full milk diet (Table 2). Arachis oil was used as a source of fat and sucrose for carbohydrate. A comprehensive mineral mixture (A) was used as well as a small amount of a second more alkaline mineral mixture (B) which had to be added to prevent coagulation of the milk proteins by the acidity of the amino acid mixture. Vitamins were provided as mixtures in two solutions, A and B.

The diet was prepared as follows: The arachis oil, a teaspoonful of acacia powder and $150 \mathrm{ml}$. of hot boiled water was placed in a 'Kenmix' food mixer. After 30 seconds at half speed, a further $150 \mathrm{ml}$. of boiled water, 
to which had been added the amino acid mixture, the mineral mixture, the sucrose and the required quantity of milk, was placed in the mixer. Again, after mixing at half speed for one minute, the mixture was transferred to a one-litre bottle and diluted with warm boiled water to the desired volume $(500 \mathrm{ml}$. or more). After adding the vitamin supplement the bottle was shaken and stored in a refrigerator. This quantity provided the food for one day and was divided to give six four-hourly feeds. Each feed was warmed before being given.

When L.O'C., at 6 days old, was put on this diet she was allowed $75 \mathrm{ml}$. of skimmed cows' milk each day. The quantities of the remaining constituents are given in Table 2. The mixture was made up to $600 \mathrm{ml}$. and divided into six equal portions. This amount of milk supplied about $97 \mathrm{mg}$. of leucine, $67 \mathrm{mg}$. of isoleucine and $60 \mathrm{mg}$. of valine (by calculation) per $\mathrm{kg}$. body weight of the child. These quantities are lower than those required for maintenance of growth, but this was unimportant at this stage since the infant's tissues and fluids were overloaded with these amino acids. The blood plasma level of isoleucine $(0.23 \mathrm{mg}$. $/ 100 \mathrm{ml}$.) was too low when measured on day 11 and a daily supplement of $100 \mathrm{mg}$. of isoleucine was added to the mixture until the milk was increased to $100 \mathrm{ml}$. on the sixteenth day. The patient was taking the feed well and growth was satisfactory. On the 32 nd day the milk was increased to $110 \mathrm{ml}$. (leucine $120 \mathrm{mg}$., isoleucine $80 \mathrm{mg}$. and valine $77 \mathrm{mg} . / \mathrm{kg}$.). Blood plasma levels of these amino acids two days later indicated that the valine intake was too low $(0.48 \mathrm{mg}$. per $100 \mathrm{ml}$.). $50 \mathrm{mg}$. of valine was now added to the dietary mixture each day. With growth well maintained $(3.7 \mathrm{~kg}$.) the milk was increased by $10 \mathrm{ml}$. increments at intervals of about 11 days.

At the beginning of the third 28-day dietary period (Table 2) an adjustment was made to the amino acid mixture to allow for the addition of $5 \mathrm{~g}$. of gelatin each day. L.O'C. was now receiving $133 \mathrm{mg}$. of leucine, $88 \mathrm{mg}$. of isoleucine and $92 \mathrm{mg}$. of valine per $\mathrm{kg}$. About one-quarter of these quantities was dervied from the gelatin and the remainder was contributed by $120 \mathrm{ml}$. of skimmed milk. This mixture provided a slightly higher proportion of valine and the additional valine supplement of $50 \mathrm{mg}$. per day was discontinued. The infant continued to thrive on this mixture and the blood plasma levels of leucine, isoleucine and valine were only slightly above the normal range. The diet was now providing about $125 \mathrm{kcal}$. per $\mathrm{kg}$. weight of the child. For the fourth dietary period further increases were made, including a $15 \%$ increase in the amino acid mixture and gelatin as well as additional milk to $130 \mathrm{ml}$. Mashed cooked carrot and/or apple purée, two teaspoonfuls twice a day, were now given. Except for adjusting the milk intake to $135 \mathrm{ml}$. the remaining items in the diet were unchanged for the fifth period. L.O'C. had a mild infection that caused a lapse in her weight gain. However, as an additional safeguard against a shortage of some unknown growth factor $5 \mathrm{~g}$. of fresh baker's yeast was given each day. About one-half of this quantity was creamed with a teaspoonful of sucrose and added to each of two of the liquid feeds.
For the sixth and seventh diet periods further increases were made, notably to the essential amino acids phenylalanine, methionine, threonine and tryptophan. The yeast was increased to $10 \mathrm{~g}$. and the carrot and fruit purées were used more liberally. For convenience, as L.O'C. would soon be cared for at home, the liquid skimmed milk (135 ml.) was replaced by $13.4 \mathrm{~g}$. of skimmed milk powder which was incorporated with the amino acids and gelatin as one mixture.

Before L.O'C.'s discharge from U.C.H., Mrs. O'C. was admitted to hospital and given instruction in the care of the child and in the preparation of the diet. It was necessary to provide her with the necessary equipment to carry this out at home (refrigerator, mixer, measures, etc.). She was also given cartons of amino acid mixture, mineral mixture, acacia powder and vitamin supplements at 14-day intervals when she attended with L.O'C. as an out-patient.

During the next three months the basic diet remained much the same except that the gelatin was raised to $7 \mathrm{~g}$. and the milk powder to $15 \mathrm{~g}$. per day. To provide enough calories the fat and sucrose were increased (Table 2) and gluten-free flour was used to thicken the feeds and for making rusks. When L.O'C. was readmitted with otitis media at 8 months the milk powder was omitted from the diet for four days at the height of her fever. It was gradually restored and by the ninth day she was having $13 \mathrm{~g}$. of the powder and by the $21 \mathrm{st}$ day when she returned home, she was again having $15 \mathrm{~g}$. of milk powder per day.

At $10 \%$ months she was again admitted to U.C.H. after several bouts of vomiting. No cause for the sickness was found and she quickly recovered. However, while in hospital the opportunity was taken to make further changes in her diet. The amino acid mixture and mineral mixture and vitamin supplements remained as before, but the dried skimmed milk was replaced with $140 \mathrm{ml}$. of fresh whole cows' milk. The basic mixture (less milk) was made up to $800 \mathrm{ml}$. to provide four feeds of $200 \mathrm{ml}$. With two of these feeds $2 \mathrm{oz}$. (one half tin) of Heinz Junior Foods was also given. The leucine, isoleucine and valine content of the food was calculated (an approximate calculation based on the figure for protein content as declared by the manufacturer) and equated with an equivalent quantity of milk. This amount of milk was deducted from the $140 \mathrm{ml}$. allowed daily. The more proteinaceous foods had a fairly high milk equivalent, for instance, $2 \mathrm{oz}$. of 'vegetables and beef' replaced $55 \mathrm{ml}$. of milk, while those containing more carbohydrate, e.g. 'pineapple rice pudding' required only the deduction of $18 \mathrm{ml}$. of fresh milk. The remaining two feeds of the day shared the quantity of milk remaining after the deductions had been made. The prepared foods gave a much-needed variety to the diet and the patient has responded well to the change.

At the time of writing this account L.O'C. is just over 1 year old and her diet remains as stated above.

\section{Discussion}

The successful treatment of this child has confirmed the belief that maple syrup urine disease 
can be treated solely by dietary means. The natural evolution of the disease is so spectacular that its substitution by normal growth and development allows of no doubt as to the efficacy of the treatment. We are not presented with the much slower rate of mental deterioration found for instance in phenylketonuria, where the results of treatment have been far more difficult to assess. From the clinical signs and from the evidence of normal amino acid levels in the cord blood it can be assumed that the child was unharmed at the time of birth. Presumably the foetus was protected from any excessive quantities of the branched-chain amino acids or their keto acid analogues by the placenta. Examination of a urine sample passed by the mother just before delivery of the child had shown a normal amino acid and keto acid excretion. The rapid rise of blood plasma concentration of leucine and to a slightly less extent of isoleucine and valine during the first few days after birth was particularly alarming. This may well be the cause of the early deaths (12-14 days) so frequently reported in this disease. It also emphasizes the need for very early diagnosis and prompt corrective treatment. In most instances it will be very difficult to diagnose the disease and organize a suitable diet in time to alleviate all the effects of the disease, but once it is known that a family has this trait, as in our case, then further siblings should be watched with great care.

So far, the child has taken the diet without demur. This is probably because it was given so early and before her taste was discriminatory. The taste of the mixture is not unpleasant, but a rather obnoxious flavour is sometimes encountered in the samples of 1-methionine used. One of the hazards in the treatment of children with fully synthetic diets is in the provision of all the necessary growth factors. Even if all the known vitamins are included it is by no means certain that the diet is complete nutritionally. Therefore it is wise to incorporate a proportion of natural foods at the earliest opportunity. For this reason it was decided to use milk, albeit in small amounts, rather than to add measured amounts of synthetic leucine, isoleucine and valine to the diet. Later, on the recommendation of Dr. L. E. Holt, Jr., fresh yeast was used. Also, for somewhat similar reasons, gelatin, which has a relatively low content of the branched-chain amino acids, was used after the first two months to provide more whole protein. It was also considered to be advantageous because the release of the amino acids in the gut would cover a longer time. Previously to this the feeds were not satisfying the child for the whole period between feeds.
The patient has remained close to the 10th percentile for weight and on the 25th percentile for height. The policy of restricting the intake of the branched-chain amino acids may have erred, at times, by causing a sub-optimal level of these amino acids in the tissue fluids. This may have caused a partial limitation of her growth.

The patient's mental and neurological development, as far as can be ascertained at present, has proceeded normally. She has had a normal electroencephalogram throughout.

Apparently the high levels of leucine, isoleucine and valine in the tissues during the few days after birth have not resulted in any permanent harm and it was particularly gratifying to find that the electroencephalogram was still normal during one of her febrile attacks when the blood plasma level of leucine due to the release of this amino acid from endogenous protein breakdown rose to $22 \mathrm{mg}$. per $100 \mathrm{ml}$. This leads one to hope that, as she gets older, occasional childish ailments or occasional dietary lapses will cause no more harm than befalls the temporarily unbalanced diabetic in similar circumstances.

The buffer solutions that have been used in the automatic amino acid analyser did not separate methionine from alloisoleucine and we could only assume that the latter substance was present in the blood plasma of the patients because the 'methionine' peak was always much too large. For the most recent analysis we have used the Varigrad system of buffers (Piez and Morris, 1960) which will resolve the mixture of methionine and alloisoleucine and two separate peaks have been obtained. It is reasonably certain therefore that the patient has had alloisoleucine circulating in her tissue fluids since birth. This supports the finding of Norton et al. (1962) who reported the presence of alloisoleucine in a patient with maple syrup urine disease. The presence of alloisoleucine has not been reported, as far as I am aware, in any natural foodstuff but it does frequently arise, as a contaminant, in certain samples of synthetic isoleucine. Since L.O'C. has received her isoleucine from natural sources, apart from a small supplement given to her when she was between 10 and 14 days old, it must be assumed that her alloisoleucine has been formed endogenously. It might arise by enolization and amination of the keto acid analogues of isoleucine ( $\alpha$-oxo $\beta$-methylvaleric acid) which has been shown to be present in the blood plasma in this disease (Dent and Westall, 1961). In view of the satisfactory neurological status of the patient it seems unlikely that the presence of this unnatural amino acid has any harmful effect. This is borne out by some work 
on the toxicity of certain amino acids by Gullino, Winitz, Birnbaum, Cornfield, Otey and Greenstein (1956). They found that alloisoleucine, either in the D or L form, was the least toxic when given intraperitoneally, and in large doses, to rats, of a series of amino acids tested, which included all the essential amino acids.

With regard to the cost of the treatment, the price of materials used in the diet during the first two months was about 30 shillings per day. This figure would have increased to about 50 shillings per day when the child was 1 year old if the same mixture had been used throughout. The use of gelatin to replace part of the synthetic amino acid mixture had led to a considerable economy and, at the present time, the cost of the materials used in the diet is about 20 shillings per day. In a previous communication (Dent and Westall, 1961) a method was outlined for preparing a suitable amino acid mixture by removing the branched-chain amino acids from a casein hydrolysate. At that time we considered that this would be a cheaper way of supplying the necessary amino acids for the diet, but with synthetic amino acids becoming more readily available and at somewhat lower prices than before, it is now doubtful if our original suggestion would lead to any appreciable economy. The cost of the present diet could be reduced considerably if the three more expensive non-essential amino acids, alanine, proline and serine were omitted and an equivalent amount of amino nitrogen supplied by other less costly amino acids such as glutamic acid or glycine. However, in a vital trial of this nature it was not considered safe to do so.

\section{Summary}

A 6-day-old baby with a confirmed diagnosis of maple syrup urine disease has been treated with a diet containing the minimum amounts of leucine, isoleucine and valine required for maintenance of normal or only slightly raised plasma levels.

At 1 year of age the mental and neurological status of the child is normal, and it is believed that the controlled diet has prevented the onset of the serious cerebro-degenerative changes that occur with the disease when left untreated.

The rapid accumulation in the first few days of the branched-chain amino acids and of their keto acid analogues in the tissue fluids, when the baby was fed on a milk diet, makes it imperative to diagnose the disease as soon as possible and to institute the special diet as rapidly as possible.

The author would like to acknowledge with gratitude the generous gifts of amino acids donated by the Sigma Chemical Company, St. Louis, Missouri, U.S.A., and by the National Institutes of Health, Bethesda, U.S.A.

I would also like to record my appreciation of the help and advice afforded to me by Professor C. E. Dent, Dr. R. E. Bonham Carter and Dr. A. Costello, who were responsible for the medical care of the patient. Finally I would like to thank the Sisters and Nurses of the Obstetric and Paediatric departments, the Dietitians and Pharmacists of University College Hospital, as well as my colleagues in the Medical Unit, without whose wholehearted co-operation such a project could not have been carried out.

\section{REFERENCES}

Bloxam H. R., Day, M. G., Gibbs, N. K. and Woolf, L. I. (1960). An inborn defect in the metabolism of tyrosine in infants on a normal diet. Biochem. J., 77, 320.

Dancis, J., Levitz, M., Miller, S. and Westall, R. G. (1959). 'Maple syrup urine disease.' Brit. med. J., 1,91.

Dent, C. E. and Westall, R. G. (1961). Studies in maple syrup urine disease. Arch. Dis. Childh., 36, 259.

Gullino, P., Winitz, M., Birnbaum, S. M., Cornfield, J., Otey, M. C. and Greenstein, J. P. (1956). Metabolism of amino acids and related compounds in vivo. 1. Toxicity of essential amino acids, individually and in mixtures, and the protective effect of $\mathrm{L}$ arginine. Arch. Biochem. $64,319$.

Holt, L. E., Jr., Snyderman, S. E., Dancis, J. and Norton, P. M. (1960). The treatment of a case of maple syrup urine disease. Fed. Proc. 19,10

Levine, S. Z., Gordon, H. H. and Marples, E. (1941). A defect in the metabolism of tyrosine and phenylalanine in premature infants, II. Spontaneous occurrence and eradication by vitamin C. J. clin. Invest., 20, 209.

Mackenzie, D. Y. and Woolf, L. I. (1959). 'Maple syrup urine disease.' An inborn error of the metabolism of valine, leucine, and isoleucine associated with gross mental deficiency. Brit. med. $J$. 1,90 .

Menkes, J. H. (1959). Maple syrup disease; isolation and identification of organic acids in the urine. Pediatrics, 23, 348.

- Hurst, P. L. and Craig, J. M. (1954). A new syndrome progressive familial infantile cerebral dysfunction associated with an unusual urinary substance. ibid., 14, 462.

Moore, S. and Stein, W. H. (1954). Procedures for the chromatographic determination of amino acids on four per cent crosslinked sulfonated polystyrene resins. J. biol. Chem. 211, 893

Norton, P. M., Roitman E., Snyderman, S. E. and Holt, L. E., Jr. (1962). A new finding in maple-syrup-urine disease. Lancet, $1,26$.

Piez, K. A. and Morris, L. (1960). A modified procedure for the automatic analysis of amino acids. Analyt. Biochem., 1, 187.

Spackman, D. H., Stein, W. H. and Moore, S. (1958). Automatic recording apparatus for use in the chromatography of amino acids. Anal. Chem., 30, 1190.

Westall, R. G., Dancis, J. and Miller, S. (1957). Maple sugar urine disease. A.M.A. Amer. J. Dis. Child., 94, 571. 